\section{初療機関でくも膜下出血と診断できなかった 頭痛患者に関する検討}

\section{Clinical Study on Patients with a Headache who Could not be Correctly Diagnosed as Having a Subarachnoid Hemorrhage during Their First Hospital Visit}

\author{
Yukinori Imao, M.D., and Hirotaka WATARAI, M.D. \\ Department of Neurosurgery, Hashima City Hospital, Hashima, Gifu, Japan
}

\author{
Key words: \\ - subarachnoid hemorrhage \\ - headache \\ $\cdot$ initial misdiagnosis
}

Surg Cereb Stroke

(Jpn) 44: 283-287, 2016

\section{はじめに}

くも膜下出血の中には, 頭痛の存在が明らかでなく, そ れを疑うことすら困難な症例もある。しかし，頭痛が主訴 の場合は，鑑別診断の中にくも膜下出血は含まれるべきで あり，初診時に除外が必要な疾患である．今回われわれ は，頭痛を主訴として受診したにもかかわらず，初療機関
で正しく診断できなかったために確定診断が遅れたくも膜 下出血症例について検討したので報告する.

\section{対象と方法}

1998 年 5 月から 2014 年 4 月までの 16 年間に当院でく も膜下出血と診断された症例は，235 例であった。このう ち, 初診時に正しく診断されなかったために, くも膜下出

羽島市民病院 脳神経外科(受稿日 2015. 9. 30) (脱稿日 2016. 3. 1) 〔連絡先： T 501-6206 岐阜県羽島市新生町 3-246 羽島市民病院 脳神 経外科 今尾幸則] [Address correspondence: Yukinori ImAO, M.D., Department of Neurosurgery, Hashima City Hospital, 3-246 Shinseicho, Hashima, Gifu 501-6206, Japan] 


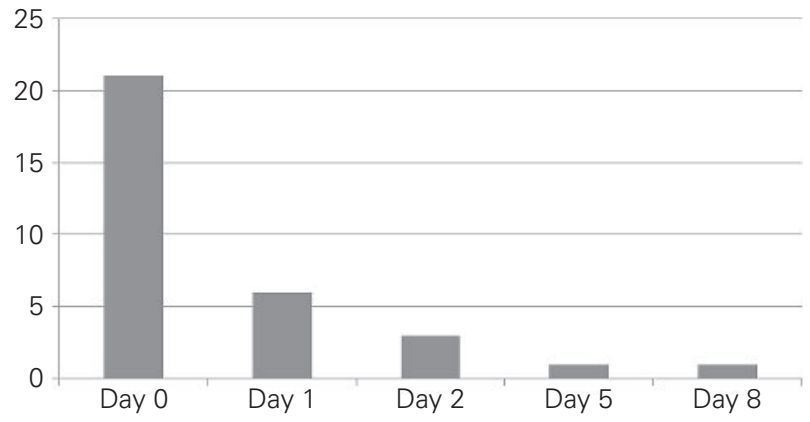

Fig. 1 Day of first visit.
Table 1 Symptoms accompanying headache

Nausea / vomiting: 21

Neck pain: 5

Chills: 3

Oculomotor nerve palsy: 3

Weakness in the lower extremities: 2

Vertigo: 1

Hearing loss: 1

Earache: 1

Diarrhea: 1

Table 2 Diagnosis at first visit

Common cold: 6

Acute gastroenteritis: 3

Cervical spine sprain: 2

Tension headache: 2

Migraine: 1

Hypertension: 1

Food poisoning: 1

Meningitis: 1

Diplopia: 1

Unspecified diagnosis: 14

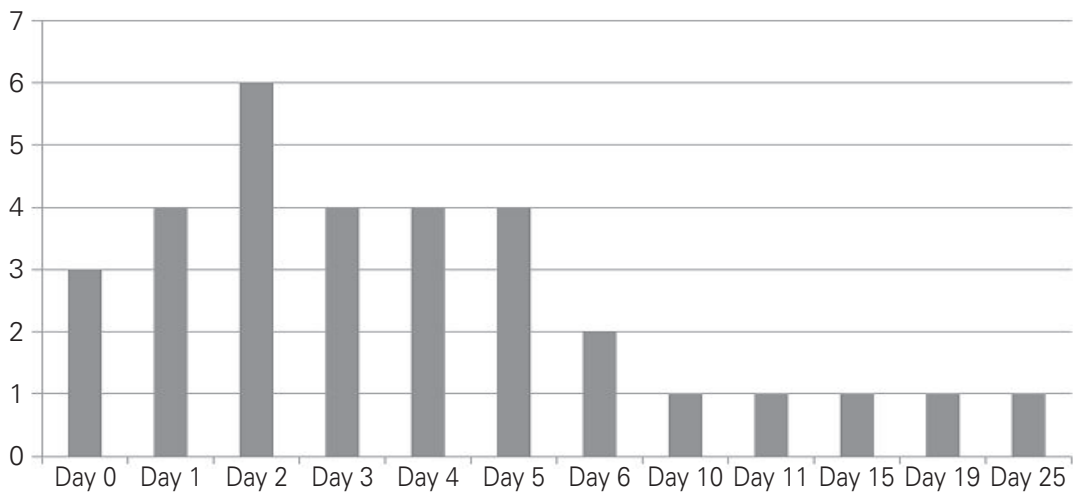

Fig. 2 Day of definitive diagnosis.
血の診断が遅れた症例について発症から初診までの期 間, 受診手段, 初診時の神経学的重症度, 頭痛に随伴する 症状, 初診担当医の診療科, 初診時診断, 初診時における 頭部 CT の実施状況, 確定診断日と確定診断されるまでの 受診回数, 確定診断時の神経学的重症度について検討した.

なお, くも膜下出血の診断の遅れの定義は, 患者が医療 機関を初めて受診した際に突然発症の頭痛などくも膜下出 血の発症が強く疑われる病歴があるにもかかわらず，初診 の医療機関から専門医へ紹介されることなく帰宅してしま い, 2 回目以降の診察で確定診断された場合とした.

\section{結果}

初診時にくも膜下出血と診断できなかったと考えられた 症例は，32 例 $(13.6 \%)$ であった. 1) 初診日：発症当日 21 例, 翌日 6 例, 翌々日以降 5 例であり，8 割以上の患者は 発症翌日までに医療機関を受診していた(Fig. 1)。2)受診 手段：全例が徒歩受診であった３）初診時の神経学的重症 度: Hunt \& Kosnik grade 1 が 22 例, 2 が 10 例であり, $2 / 3$ 以上の症例で頭痛は軽度であった４）頭痛に随伴する 症状 : 嘔気・嘔吐が最も多く (21 例), 澒部痛 (5 例), 悪寒 (3 例), 動眼神経麻痺 (3 例), 下肢脱力 (2 例) などがみら れた (Table 1)。5) 初診担当医の診療科：30 例は内科医 $(22$
例は開業医，8例は病院勤務医）が初診を担当していた。 残り 2 例のうち 1 例は一般外科医, 他の 1 例は救急科医師 が初診を担当していた。 6) 初診時診断：感冒 (6 例)，急性 胃腸炎 (3 例), 澒椎捻挫 (2 例), 緊張型頭痛 (2 例) などが みられたが, 診断名を明らかにされなかった症例(14 例) が最も多かった（Table 2)．7）CT 装置を有する医療機関を 受診したのは 11 例であった。このうち実際に CT 検査が 実施されたのは 3 例のみであり，いずれも軽度のくも膜下 出血であったため初診医により異常なしと診断されてい た. 8)くも膜下出血と確定診断された日：発症日を day 0 とすると day 2 が最も多く, 最長はday 25 であった(Fig. 2).9)確定診断されるまでの受診回数：2回 18 例, 3 回 10 例, 5 回 4 例であった. 10) 確定診断時の神経学的重症 度 : Hunt \& Kosnik grade $1+2$ が 23 例, 3 が 2 例, 4 が 3 例, 5 が 4 例であった.

\section{症例}

52 歳, 男性.

day 0 の午後 10 時頃, 飲酒後に突然後頭部痛と嘔気が 出現したが，そのまま寝てしまった，翌朝になっても頭痛 が持続していたため, day 1 に A 医院を受診したところ鎮 痛剂を処方された。 day 2 になっても頭痛が改善しないた 

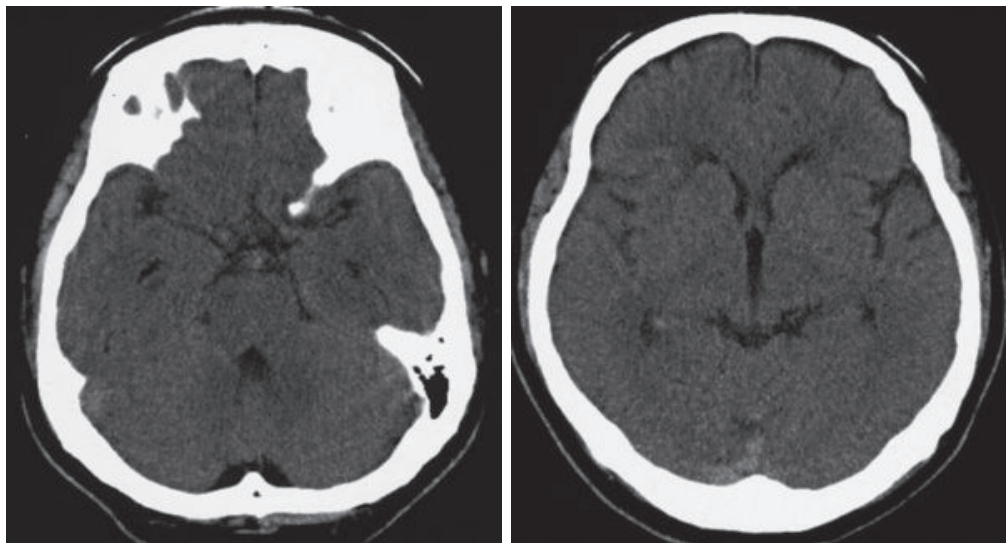

\section{\begin{tabular}{l|l} 
A & B \\
\hline C & D
\end{tabular}}

Fig. 3 Computed tomographic image obtained on day $4(\mathbf{A}, \mathbf{B})$ showing no subarachnoid hemorrhage.

Magnetic resonance imaging fluid-attenuated inversion recovery sequences obtained on day 6 (C, D) showing no subarachnoid hemorrhage.
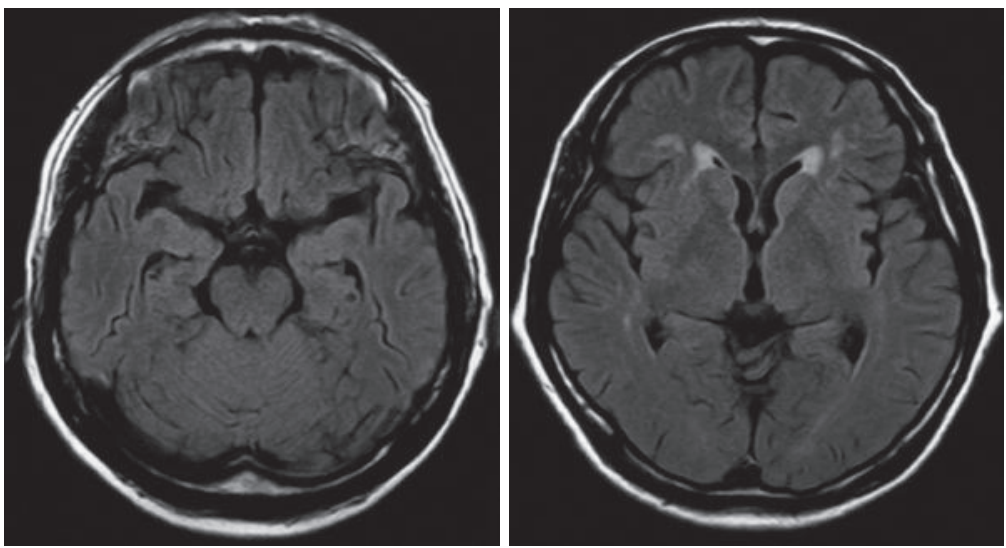

め，ふたたび A 医院を受診したところ，高血圧を指摘さ れて降圧剂が処方された。発症から 4 日が経過しても頭痛 と嘔気がつづくため, day 4 に当院救急外来を受診した. 頭部 CT (Fig. 3A，B) で明らかな異常を認めなかったため, ドンペリドンが処方されて経過観察することになった。 day 5 になっても頭痛と嘔気が消失しないため, A 医院を 受診したところ, 当科での精査をすすめられて, day 6 に 当院へ紹介された。同日，MRI 検査を行ったところ MRI (Fig. 3C，D）では明らかな異常を認めなかったが, MRA (Fig. 4) で脳底動脈先端部に脳動脈瘤を認めた。引き続き 腰椎穿刺を施行したところ血性髄液が認められ，くも膜下 出血と確定診断された。同日, 全身麻酔下にコイル塞栓術 が行われ, day 27 に modified Rankin Scale (mRS)0 で退 院した.

\section{考察}

くも膜下出血の症状は,「後頭部を突然バットやハン マーなどで殴られたような痛み」「後頭部に雷が落ちたよ うな痛み」などと表現されるように, 突然後頭部に激痛が 生じることで有名であるが，すべてのくも膜下出血患者で このような典型的な症状を呈するわけではない，突然のこ れまでに経験したことのないような激烈な頭痛で発症する

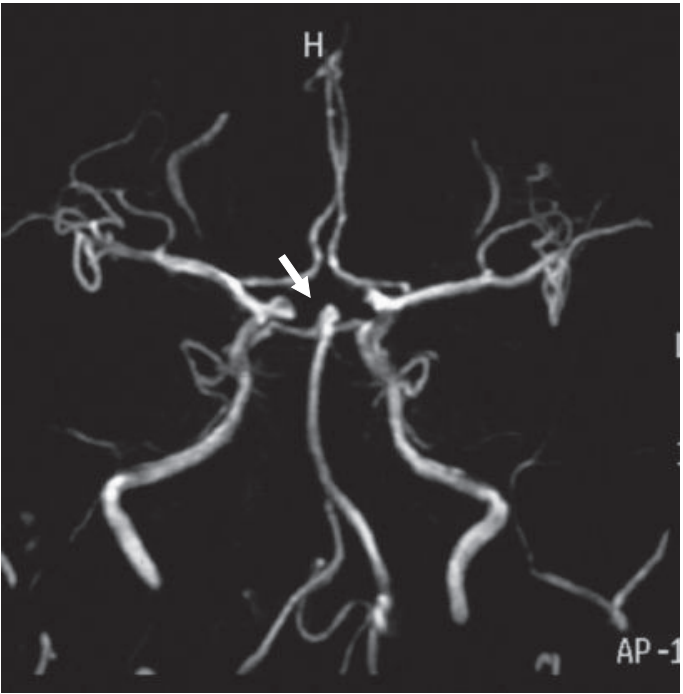

Fig. 4 Magnetic resonance angiogram obtained on day 6 showing a basilar top aneurysm (arrow).

のはくも膜下出血全体の $80 \%$ 程度ともいわれており ${ }^{10)}$, 出血が少量の場合の頭痛はそれほど強くないことも多 い. したがって, 患者も医療者も頭痛の程度からくも膜下 出血を疑わない場合があると思われる. 
Table 3 Frequency of initial misdiagnosis

\begin{tabular}{ll}
\hline 朽木ら (2014) & $8.1 \%$ \\
Yamada et al. (2013) & $6.1 \%$ \\
Inagawa $(2011)^{4)}$ & $13 \%$ \\
柴山ら (2010) $^{12)}$ & $4.9 \%$ \\
Vermeulen (2007) & $5.4 \%$ \\
Kowalski et al. $(2004)^{5)}$ & $12 \%$ \\
\hline
\end{tabular}

しかし, いかに軽症のくも膜下出血であっても再出血を 起こすと重症化する可能性が高くなるため，できるだけ早 く確定診断すべきであることは論を待たない．

過去の報告によれば，初診時にくも膜下出血が見逃され る割合は 4.9-13\% ${ }^{4)-6) 12215) 16)}$ といわれている(Table 3). 特 に歩いて受診してくるような頭痛患者ではその割合は高 く, 朽木ら ${ }^{6}$ は $27 \%$ の患者で初診時の診断が困難であった と報告している.

では，どんな理由でくも膜下出血は見逃されてしまうの であろうか? 初回診察時に見逃されるくも膜下出血はほ とんどが minor leak といわれる軽症例であるため ${ }^{1558) 141}$ ， 意識障害はなく自ら歩いて医療機関を受診できるような walk in SAH であることが多い. したがって，患者自身も くも膜下出血のような重篤な疾患を考えておらず，鎮痛剂 を内服して様子をみることで医療機関を受診するタイミン グが遅れがちになる。朽木ら ${ }^{6)}$ は, walk in SAH では発症 から医療機関受診までが平均 2.2 日と遅かったことが診断 の遅れや診断の困難さにつながったと考察している。ま た，曲沢ら ${ }^{7)}$ は独歩で外来を受診した軽症例では頭痛発症 から受診までの期間が平均 5 日であったと報告している.

くも膜下出血が疑われた場合, 最初に行われる検査は頭部 CTであるが, くも膜下腔に出た血液は時間の経過ととも に髄液で希釈されてしまうため, 発症から CT 実施までの 時間が長くなるほどCTによる診断が困難になる. Perry $ら^{10)}$ は, 最近の第 3 世代の CT を使用しても確実にくも膜 下出血の診断ができるのは, 発症から 6 時間以内に CT が 行われた場合のみと報告している。すなわち，発症から 6 時間を過ぎたら，〈も膜下出血の診断に CT は絶対ではな いということであり, Yamada $~^{16)}$ も発症から最初の検査 までが 4 日以上になると有意に誤診されやすくなると報告 している。 したがって，一般市民にもくも膜下出血の症状 を正しく理解してもらい, くも膜下出血かもしれないと 思ったら，できるだけ早くCT 装置を有する医療機関を受 診してもらうことも，誤診を減らすうえで重要なことでは ないかと思われる，実際，〈も膜下出血に関する教育，啓 蒙を行うことで，これらが行われなかった地域と比べてく も膜下出血の見逃しが $77 \%$ 減少したという報告もあ
$り^{3)}$ ，患者教育の重要性が明らかにされている.

今回の検討では, 初療機関におけるくも膜下出血の見逃 しは, 初療医がくも膜下出血を疑っていないことが主な原 因であった，初診時に患者から「後頭部を突然バットで欧 られたようなひどい頭痛を感じたので受診しました」とい われれば，大部分の医師はくも膜下出血を鑑別診断に挙げ ると思われるが，日常診療の中でそういう表現をする患者 はほとんどいない。 また，くも膜下出血では嘔気や嘔吐を 伴うことが多いといわれているが, 曲沢ら ${ }^{7)}$ はくも膜下出 血の診断が遅れた 26 例のうち嘔気, 嘔吐は 11 例にしかみ られなかったと報告している.ささらに, Yamada ${ }^{16)}$ は, 初診時に誤診された頭痛患者 30 例のうち 11 例では, 頭痛 のみであったと報告しており, 今回のわれわれの検討でも 32 例中 9 例が頭痛のみであった。 したがって, 症状が頭 痛のみで嘔気や嘔吐のない患者では, 風邪や片頭痛, 緊張 型頭痛などと誤診されやすいと考えられる ${ }^{5)}$. では, 初療 医はどのような頭痛のときにくも膜下出血を疑わなければ ならないのであろうか？まず, 突然発症で即座に痛みが ピークに達する頭痛であるということが最も強調されるべ き点と考えられる ${ }^{11)}$. したがって, 患者に頭痛がいつ起 こったかを尋ねると「午前中」とか「昼頃」とかいう曖昧 なものではなく，「朝食を食べ始めた直後」や「トイレで 排便していたとき」など具体的な発症時間の回答が得られ ることが多い，また，頭痛は数時間で消失することはな く, 鎮痛郕などでいったんは改善してもふたたび頭痛が出 現し，数日間は持続することが多(2025)913116). 以上より, 突然発症の頭痛で短時間のうちに痛みがピークに達し, な おかつ頭痛が長く続く場合は, たとえ頭痛の程度が軽 く, 歩いて受診した患者であったとしても, くも膜下出血 を疑って診察しなければならないと思われる.

医療者側の要因として，CT 所見の見落としの問題も挙 げられる。柴山ら ${ }^{12)}$ は，くも膜下出血の診断が遅れた 13 例中 8 例で頭部 CT が行われていたが，このうち 6 例では 正しく読影されていなかったと報告している. 診療所や救 急外来などで頭痛を主訴として来院する患者を診察する可 能性のある医師は, 典型的なくも膜下出血の CT 所見とと もに軽症くも膜下出血やある程度時間が経過したくも膜下 出血の CT 所見についても知っておいたほうがよいと思わ れる．また， CT 実施後はできるだけ早い時期に放射線科 医や脳神経外科医によるダブルチェックが行われるような 体制にすることも, 軽症くも膜下出血を見逃さないうえで 重要であると思われた.

\section{結 語}

頭痛が主訴であっても, 徒歩で受診する患者はくも膜下 出血が疑われることは少なく，CT の実施率も低かった。 
たとえ軽症であっても, くも膜下出血による頭痛は簡単に は消失しないので, 頭痛が改善しないという理由で再診す る患者では常にくも膜下出血を疑って診療を行う必要があ る.

本論文の要旨は, 第 44 回日本脳卒中の外科学会 $(2015$ 年 3 月 27 日)に扔いて発表した。著者全員は日本脳神経外 科学会への COI 自己申告を完了しており, 本論文の発表 に関して開示すべきCOIはありません.

\section{文献}

1) Adams HP Jr, Jergenson DD, Kassell NF, et al: Pitfalls in the recognition of subarachnoid hemorrhage. JAMA 244: 794-796, 1980

2) Edlow JA, Caplan LR: Avoiding pitfalls in the diagnosis of subarachnoid hemorrhage. N Engl J Med 342: 29-36, 2000

3) Fridriksson S, Hillman J, Landtblom AM, et al: Education of referring doctors about sudden onset headache in subarachnoid hemorrhage. A prospective study. Acta Neurol Scand 103: 238-242, 2001

4) Inagawa $\mathrm{T}$ : Delayed diagnosis of aneurysmal subarachnoid hemorrhage in patients: a community-based study. J Neurosurg 115: 707-714, 2011

5) Kowalski RG, Claassen J, Kreiter KT, et al: Initial misdiagnosis and outcome after subarachnoid hemorrhage. JAMA 291: 866-869, 2004

6）朽木秀雄, 小久保安昭, 近藤 礼, ほか：歩いて来た $\mathrm{SAH}$ 一軽度頭痛のみを呈するくも膜下出血について. 脳卒中の外
科 42: 122-126, 2014

7）曲沢 聡, 鈴木明文, 安井信之：〈も膜下出血診断以前に受 診歴を有する破裂脳動脈瘤例の検討一脳動脈瘤治療成績向上 のために．脳神経 46: 341-347, 1994

8) Mayer PL, Awad IA, Todor R, et al: Misdiagnosis of symptomatic cerebral aneurysm. Prevalence and correlation with outcome at four institutions. Stroke 27: 1558-1563, 1996

9) Mayer SA, Bernardini GL, Brust JCL, et al: Subarachnoid hemorrhage. In: Rowland LP(ed): Merritt's Neurology. 10th ed. Baltimore, Williams \& Wilkins, 260-267, 2000

10) Perry JJ, Stiell IG, Sivilotti ML, et al: Sensitivity of computed tomography performed within six hours of onset of headache for diagnosis of subarachnoid haemorrhage: prospective cohort study. BMJ 343: d4277, 2011

11) Perry JJ, Stiell IG, Sivilotti ML, et al: Clinical decision rules to rule out subarachnoid hemorrhage for acute headache. JAMA 310: 1248-1255, 2013

12）柴山美紀根, 市原 薰, 中林規容, ほか：非外傷性クモ膜下 出血症例の初診時 misdiagnosis の検討．市立四日市病院雑 誌, $1-6,2010$

13) van Gijin J, Rinkel GJ: Subarachnoid hemorrhage: diagnosis, causes and management. Brain 124: 249-278, 2001

14) Vannemreddy $P$, Nanda A, Kelley R, et al: Delayed diagnosis of intracranial aneurysms: confounding factors in clinical presentation and the influence of misdiagnosis on outcome. South Med J 94: 1108-1111, 2001

15) Vermeulen MJ, Schull MJ: Missed diagnosis of subarachnoid hemorrhage in the emergency department. Stroke 38: 12161221, 2007

16) Yamada T, Natori Y: Evaluation of misdiagnosed cases of subarachnoid hemorrhage and causal factors for misdiagnosis. J Stroke Cerebrovasc Dis 22: 430-436, 2013 